\title{
Comparative Study of the in vitro Antioxidant Properties of Methanolic Extracts of Chromolaena odorata and Ageratum conyzoides used in Wound Healing
}

\author{
Babatunde Joseph Oso*, Nosarieme Abey, Moses Oyedotun Oyeleke, Boyede Olowookere \\ Department of Biochemistry, Kings University, Odeomu, Osun State, Nigeria \\ * Corresponding author email: basjoe08@gmail.com
}

Received: 27 July 2018 / Accepted: 23 September 2018 / Published: 02 October 2018

ABSTRACT

\begin{abstract}
This study sought to evaluate the potential antioxidative potencies of Chromolaena odorata and Ageratum conyzoides, commonly used herbs in Nigeria for wound first aid and healing. The antioxidant potentials were evaluated by measuring their abilities to scavenge radicals, reduce oxidised iron and quench the formation of lipid peroxides. The findings showed that the extract of Ageratum conyzoides exhibited significantly higher $(p<0.05)$ antioxidant potential than the extract of Chromolaena odorata. The study therefore suggests that Ageratum conyzoides has higher potential for therapeutic value than Chromolaena odorata in terms of antioxidant potential.
\end{abstract}

Keywords: Wound, Antioxidant, Free Radicals, Phytochemicals. Chromolaena odorata, Ageratum conyzoides,

\section{Introduction}

Wound healing is a normal biological process in the body and is achieved through varieties of processes which include production of radicals to quench the bacterial pathogens at the wound site [1]. However, the process of wound healing has been hypothesised to be delayed by excessive production and accumulations of radicals and consequent effects on antiprotease bodies that usually protect tissue cells and extracellular matrix [2]. Thus, healing process requires the removal of products of inflammation which are produced as a defense mechanism against invading pathogens [3]. Thus, a tight regulation of free radical generation and clearance is essential for the normal repair process of wound healing. One of the therapeutic effects of substances used in aiding healing process at wound site is derived from the antioxidant property of the agent which helps in preserving the fibroblast and keratinocyte proliferation on those wound sites [4]. Various agents with high antioxidant properties have been used to aid the healing process and to protect tissue from oxidative damage [5]. Examples include ascorbic acid which has been used by healthcare practitioners as nutritional intervention for wound healing. This is not only associated with its role as a cofactor in proline and lysine hydroxylation during collagen formation, but also with its antioxidant and anti-inflammatory properties [6]. Topical applications of some plant juices have been used to promote repair mechanism and enhance healing process for centuries. Chromolaena odorata (commonly called Siam weed in English and Akintola in Yoruba) and Ageratum conyzoides (commonly called goat weed in English and Imiisu in Yoruba) are examples of some of the medicinal herbs that are widely used for their wound healing properties in South-Western part of Nigeria. This study was aimed at evaluating the comparative antioxidant potentials of the methanolic extracts of the leaves of Chromolaena odorata and Ageratum conyzoides.

\section{Materials and Methods}

\subsection{Chemicals}

Chemicals used in this study comprise of 2,2azinobis (3-ethylbenzothiazoline-6-sulfonic acid) diammonium salt (ABTS), potassium 
ferricyanide, thiobarbituric acid, ascorbic acid, dimethyl sulfoxide, 2,2-diphenyl-1-picrylhydrazyl (DPPH) and trolox.

\subsection{Preparation of the Extracts}

Fresh leaves of Chromolaena odorata and Ageratum conyzoides were obtained from local areas in Odeomu, Osun State, Nigeria. The samples were authenticated by Mr Olowookere, Department of Biochemistry, Kings University. The leaves were cleaned and dried in the shade, then the dried samples were pulverised and stored in an airtight container at room temperature $\left(29^{\circ} \mathrm{C}\right)$. One gram each of the pulverised samples was macerated and immersed in methanol for 48 hours and filtered through filter paper. The extracts obtained were concentrated and reconstituted in methanol for subsequent analyses.

\subsection{Determination of Antioxidant Activity by the DPPH• Scavenging Potential}

The DPPH $\bullet$ assay was carried out as described by Shirwaikar et al. [7]. Precisely $0.15 \mathrm{ml}$ of varying concentrations $(20 \mu \mathrm{g} / \mathrm{ml}-100 \mu \mathrm{g} / \mathrm{ml})$ of each extract was added to $0.1 \mathrm{ml}$ of the solution of $\mathrm{DPPH} \cdot(0.1 \mathrm{mM})$. The reaction was left in the dark for 30minutes and afterwards, the optical density (OD) of the reaction was read at $517 \mathrm{~nm}$. The percentage inhibition was calculated as follow:

$$
\% \text { Inhibition }=\frac{\text { OD of blank }- \text { ODof sample }}{\text { OD of blank }} \times 100
$$

\subsection{Hydrogen Peroxide Scavenging}

The ability of the extracts to scavenge $\mathrm{H}_{2} \mathrm{O}_{2}$ was assessed as described by Ruch et al. [8]. Different concentrations $(20 \mu \mathrm{g} / \mathrm{ml}-100 \mu \mathrm{g} / \mathrm{ml})$ of the sample $(0.15 \mathrm{ml})$ were added to $0.05 \mathrm{ml}$ of hydrogen peroxide solution $(20 \mathrm{mM})$. After 10 minutes, the OD was read at $230 \mathrm{~nm}$. The percentage scavenging of $\mathrm{H}_{2} \mathrm{O}_{2}$ was calculated as follow:

$$
\% \text { Scavenging }=\frac{\text { OD of blank }- \text { OD of sample }}{\text { OD of blank }} \times 100
$$

\subsection{Inhibition of Lipid Peroxidation}

This reaction was carried out in accordance to the methods described by Ruberto et al. [9] with slight modification. Briefly, $0.1 \mathrm{ml}$ of egg yolk homogenate $(10 \% \mathrm{v} / \mathrm{v})$ was added to $0.5 \mathrm{ml}$ of varying concentrations of the extract in test tubes. The volume in each test up was made up to $1.0 \mathrm{ml}$ with distilled water. Afterwards, $0.05 \mathrm{ml}$ of ferrous sulfate was added and incubated at $37^{\circ} \mathrm{C}$ for 30 minutes. Then, $0.5 \mathrm{ml}$ of acetic acid-thiobarbituric acid reagent prepared in dimethyl sulfoxide was added. The resulting mixture was mixed and incubated at $95^{\circ} \mathrm{C}$ for 1 hour. Afterwards, the test tubes were allowed to cool and centrifuged at $650 \times \mathrm{g}$ for 5 minutes and the OD of the supernatant was read at $532 \mathrm{~nm}$. The percentage inhibition was calculated as follow:

$$
\% \text { Inhibition }=\frac{\text { OD of blank }- \text { ODof sample }}{\text { OD of blank }} \times 100
$$

\subsection{Ferric Reducing Antioxidant Property}

The ability of the extracts to reduce oxidised iron was carried out as defined by Oyaizu [10]. $0.5 \mathrm{ml}$ of the extract solution $(150 \mu \mathrm{g} / \mathrm{ml})$ was added to the mixture of $1.5 \mathrm{ml}$ of $0.1 \mathrm{M}$ sodium phosphate buffer $(\mathrm{pH}$ 6.7) and $0.1 \mathrm{ml}$ of $1 \%$ potassium ferricyanide. The mixture was allowed to stand at room temperature $\left(29^{\circ} \mathrm{C}\right)$ for 30 minutes after which $0.1 \mathrm{ml}$ of trichloroacetic acid solution $(4 \%)$ was added. The mixture was made up to $2.5 \mathrm{ml}$ and centrifuged at $650 \times \mathrm{g}$ for 5 minutes. Exactly $2 \mathrm{ml}$ of the supernatant was mixed with $2 \mathrm{ml}$ of distilled water and $0.5 \mathrm{ml}$ of ferric chloride solution $(0.1 \%)$. The optical density of the reaction was measured at $700 \mathrm{~nm}$ and the results were expressed in $\mathrm{mg} / 100 \mathrm{~g}$ ascorbic acid equivalent (AAE).

\subsection{Trolox Equivalent Antioxidant Capacity (TEAC)}

The assay was carried out as described by Re $e t$ al. [11]. Exactly $0.15 \mathrm{ml}$ of each extract $(150 \mu \mathrm{g} / \mathrm{ml})$ was added to the wells of the micro-plate and the reaction was initiated by adding $0.1 \mathrm{ml}$ of ABTS $^{+}$ solution $(7 \mathrm{mM}$ ABTS prepared in $2.45 \mathrm{mM}$ ammonium persulphate overnight). The absorbance of was read at $734 \mathrm{~nm}$. The antioxidant activity of each of the extract was expressed in $\mathrm{mg} / 100 \mathrm{~g}$ TEAC. 
Oso et al., Int. Ann. Sci.; Vol. 6, Issue 1, pp: 8-12, 2019

\subsection{Qualitative Phytochemical Analysis}

Phytochemical screening of different phytochemical groups in the extract was carried out according to the methods described by Harborne [12].

\subsection{Statistical Analysis}

The results were analysed by one-way analysis of variance coupled with Duncan's post hoc test at $p<0.05$ and presented as mean \pm SEM.

\section{Results and Discussion}

The presence of phytochemicals such as terpenoids, flavonoids, saponins, phenolics and tannins in the extracts was indicated by the qualitative analysis test (Table 1). Saponins and terpenoids were quantitatively and higher in AC compared to $\mathrm{CO}$, while phenolics, flavonoids and tannins were moderately present in $\mathrm{CO}$ compared to AC. The results presented in Figures 1 to 5 showed the antioxidant properties of Chromolaenaa odorata (CO) and Ageratum conyzoides (AC) compared to standard antioxidant compound such as ascorbic acid (AA) and quercetin (QU). The antioxidant values of $\mathrm{AC}$ were significantly higher than $(\mathrm{p}<0.05)$ those of $C A$ in all the in vitro assays. The measure of the effectiveness of the plant extracts was carried out by determining the half maximal inhibitory concentration $\left(\mathrm{IC}_{50}\right)$ in response to inhibitions of $\mathrm{DPPH} \bullet$, hydrogen peroxide and lipid peroxidation. The $\mathrm{IC}_{50}$ values obtained for $\mathrm{CO}$ were significantly higher with the values of $82.18 \pm 2.60 \mu \mathrm{g} / \mathrm{ml}, \quad 111.58 \pm 2.24 \mu \mathrm{g} / \mathrm{ml}$, and $78.92 \pm 5.23 \mu \mathrm{g} / \mathrm{ml}$ respectively indicating low antioxidant capacity of $\mathrm{CO}$ compared to $\mathrm{AC}$ with the $\mathrm{IC}_{50}$ values of $48.34 \pm 5.38 \mu \mathrm{g} / \mathrm{ml}, 85.44 \pm 4.53$ $\mu \mathrm{g} / \mathrm{ml}$, and $64.23 \pm 8.22 \mu \mathrm{g} / \mathrm{ml}$. respectively. Ferric ion reducing antioxidant potential and trolox equivalent antioxidant capacity expressed in $\mathrm{mg} / 100 \mathrm{~g}$ were significantly higher $(p<0.05)$ in AC compared to CO.

Table 1: Qualitative phytochemical profiling of methanolic extracts Ageratum conyzoides and Chromolaena odorata

\begin{tabular}{|c|c|c|c|c|c|}
\hline & Flavonoids & Phenolics & Saponins & Tannins & Terpenoids \\
\hline AC & + & + & +++ & + & +++ \\
\hline CO & ++ & ++ & + & ++ & + \\
\hline \multicolumn{7}{r|}{ Keys: (+++) Highly present, (++) Moderately present, (+) } \\
Present
\end{tabular}

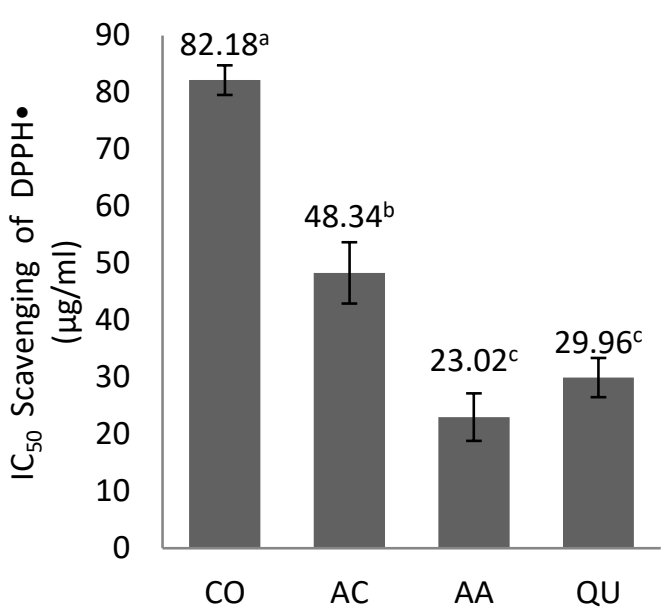

Figure 1: The in vitro DPPH• scavenging ability $(\mu \mathrm{g} / \mathrm{ml})$ of methanolic extract of Chromolaena odorata (CO) and Ageratum conyzoides (AC) compared with Ascorbic acid (AA) and Quercetin $(Q U) . I C_{50}=$ half maximal inhibitory concentration.

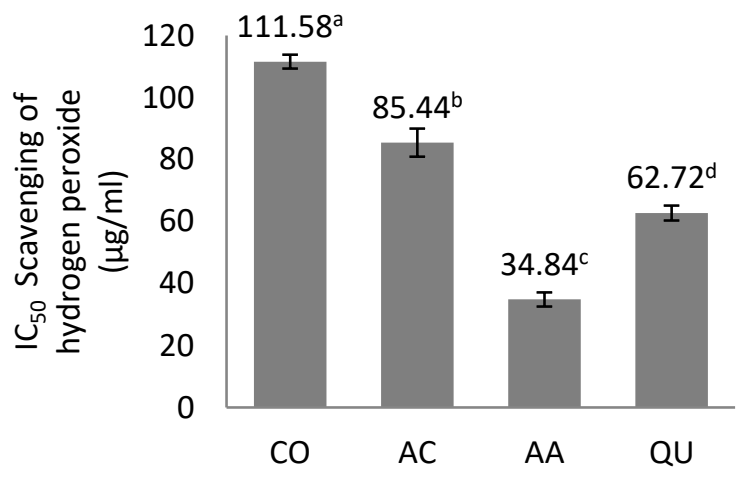

Figure 2: The in vitro hydrogen peroxide scavenging ability $(\mu \mathrm{g} / \mathrm{ml})$ of methanolic extract of Chromolaena odorata (CO) and Ageratum conyzoides (AC) compared with Ascorbic acid (AA) and Quercetin $(\mathrm{QU}) . \mathrm{IC}_{50}=$ half maximal inhibitory concentration.

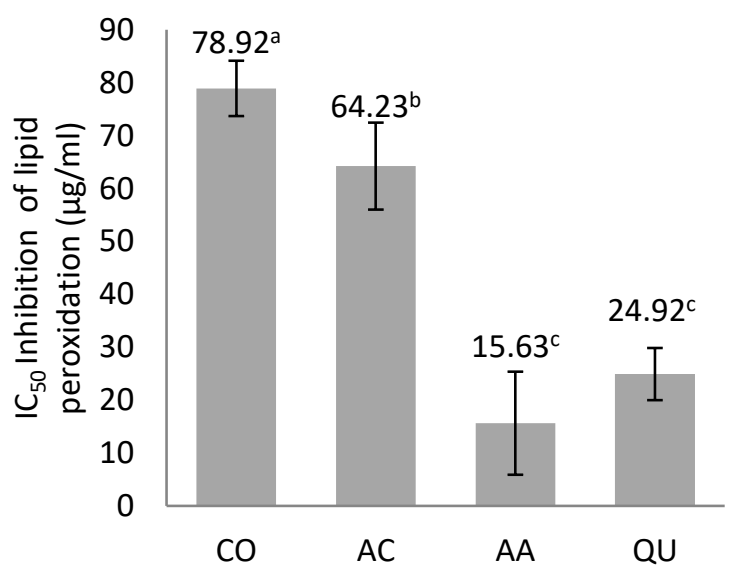

Figure 3: The in vitro lipid peroxidation inhibition ability $(\mu \mathrm{g} / \mathrm{ml})$ of methanolic extract of Chromolaena odorata (CO) and Ageratum conyzoides (AC) compared with Ascorbic acid (AA) and Quercetin $(Q U) . I C_{50}=$ half maximal inhibitory concentration. 


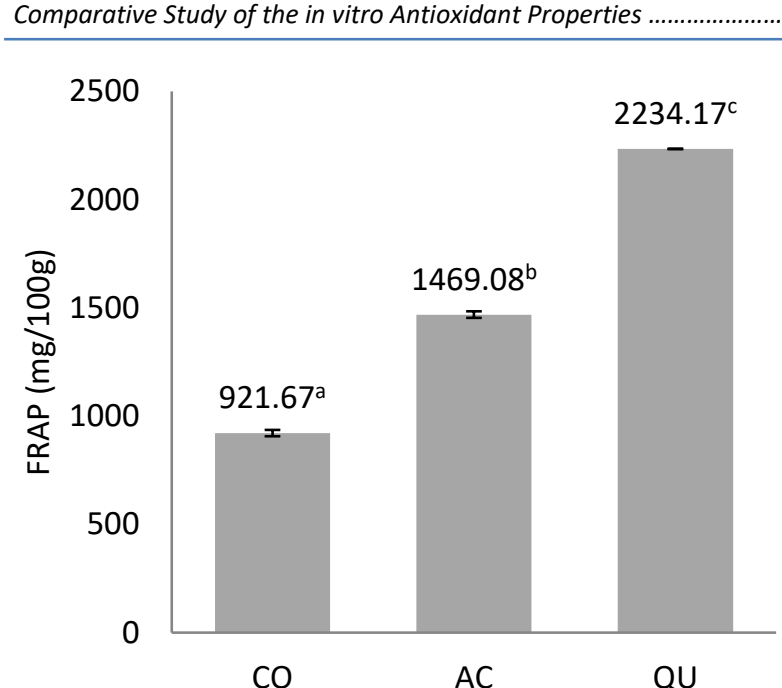

Figure 4: The in vitro ferric reducing antioxidant potential $(\mathrm{mg} / 100 \mathrm{~g})$ of methanolic extract of Chromolaena odorata (CO) and Ageratum conyzoides (AC) compared with Ascorbic acid (AA) and Quercetin (QU).

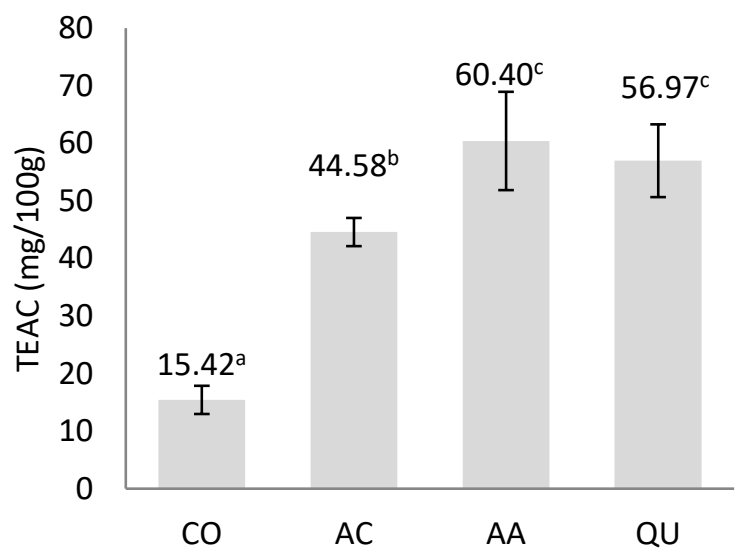

Figure 5: The in vitro trolox equivalent antioxidant capacity $(\mathrm{mg} / 100 \mathrm{~g})$ of methanolic extract of Chromolaena odorata (CO) and Ageratum conyzoides (AC) compared with Ascorbic acid (AA) and Quercetin (QU).

The therapeutic displays of many herbaceous plants in respect to wound healing are mostly due to their antioxidant properties. Antioxidants play vital roles in the prevention of tissue damage and removal of oxidants thereby promoting wound healing process [1]. The results in Figures 1 to 5 showed that the antioxidant potential of $\mathrm{AC}$ assessed based on DPPH• scavenging, hydrogen peroxide scavenging, inhibition of formation of lipid peroxides, ferric reducing antioxidant potential and TEAC was higher than the antioxidant potential of $\mathrm{CO}$. Although, ascorbic use in Wound Healing

acid (AA) used as control exhibited highest antioxidant potency followed by quercetin (QU). Commonly, the antiradical potential of antioxidative agents of botanical origin has been associated with phenolic and flavonoid contents of the botanicals and also with synergistic actions of bioactive principle that may differ in both plants [13]. The present work on the qualitative phytochemicals analysis of $\mathrm{CO}$ and $\mathrm{AC}$ showed varied presence of saponin, phenolics, flavonoids, tannins and terpenoids in the extracts. However, previous work revealed AC had alkaloids besides those detected in this report [14]. The richness of saponins and terpenoids in plant extracts had been linked to contributing to increased biological actions of many medicinal plants $[15,16]$. Phenolics and flavonoids had been found to correlate positively with antioxidant potentials of plant extracts by some earlier studies [17, 18]. Nevertheless, the combinations and subsequent synergistic of two or more phytochemicals had been inferred to bring about variations in the physiological effects and/or the bioavailability of each phytocomponent with reference to antioxidant and anti-inflammatory status [13]. Hence the absence of alkaloids and lower levels of saponins and terpenoids in CO could account for a comparatively lower antioxidant potential as shown in the result.

\section{Conclusion}

It can be hypothesised that the presence of certain constituents that vary in proportions in the botanicals might be responsible for the observed differences in the antioxidant capacity and isolation of these constituents and subsequent study of their effectiveness in promoting wound healing and on tissue repair can help in discovery of natural remedy in treatment of wounds. Therefore, it can be assumed that Ageratum conyzoides could be a promising source of natural antioxidant compounds with wound healing potentials. Further studies are suggested to explore the potential compounds from Ageratum conyzoides and in vivo studies are needed for better understanding their mechanism of action with reference to wound healing. 


\section{Declarations}

\subsection{Acknowledgements}

The authors appreciate the staff of BridgeBiotech Ltd Ilorin, Nigeria, for their technical assistance.

\subsection{Funding source}

None

\subsection{Competing interests}

The authors declared no potential conflict of interest exists.

\section{How to Cite this Article}

B. Oso, N. Abey, O. Oyeleke, and B. Olowookere, "Comparative Study of the in vitro Antioxidant Properties of Methanolic Extracts of Chromolaena odorata and Ageratum conyzoides use in Wound Healing", Int. Ann. Sci., vol. 6, no. 1, pp. 8-12, Oct. 2018. Doi: 10.21467 /ias .6.1.8-12

\section{References}

[1] B. S. Reddy, R. K. K. Reddy, V. G. Naidu, K. Madhusudhana, S. B. Agwane, S. Ramakrishna and P. V. Diwan, "Evaluation of antimicrobial, antioxidant and wound healing potentials of Holoptelea integrifolia," $J$. Ethnopharm., vol. 115, no. 2, pp. 249-256, 2007.

[2] A.Y. Mensah, J. Sampson, P. J. Houghton, P. J. Hylands, J. Westbrook, C. M. Dunn, M. A. Hughes and G. W. Cherry, "Effects of Buddleja globosa leaf and its constituents relevant to wound healing," $J$. Ethnopharmy., vol. 77, pp. 219-226, 2001.

[3] I. Süntar, E. K. Akkol, L. Nahar and S. D. Sarker, "Wound healing and antioxidant properties: do they coexist in plants?" Free Rad Antioxid, vol. 2, no. 2, pp. 1-8, 2012.

[4] M. N. Vaisakh and A. Pandey, "The invasive weed with healing properties: A review on Chromolaena odorata," Int J Pharm Sci Res., vol.3, pp. 80-83, 2012.

[5] D. Gopinath, M. R. Ahmed, K. Gomathi, K. Chitra, P. K. Sehgal and R. Jayakumar, "Dermal wound healing processes with curcumin incorporated collagen films," Biomaterials, vol. 25, pp. 1911-1917. 2004.

[6] O. Chow and A. Barbul, "Immunonutrition: Role in Wound Healing and Tissue Regeneration," Adv Wound Care, vol. 3, no. 1, pp. 46-53, 2014.

[7] A. Shirwaikar, K. Rajendran and I. S. Punithaa, "In vitro antioxidant studies on the benzyl tetra isoquinoline alkaloid berberine," Biological and Pharmaceutical Bulletin, vol. 29, pp. 1906-1910, 2006.

[8] R. J. Ruch, S. J. Cheng and J. E Klaunig, "Prevention of cytotoxicity and inhibition of intracellular communication by antioxidant catechins isolated from Chinese green tea," Carcinogenesis, vol. 10, pp. 10031008, 1989.

[9] G. Ruberto, M. T. Baratta, S. G. Deans and H. J. Dorman, "Antioxidant and antimicrobial activity of Feeniculum vulgare and Crithmum maritmum essential oils," Planta Med., vol. 66, no. 8, pp. 687-693. 2000
[10] M. Oyaizu, "Studies on products of browning reactions: antioxidant activities of products of browning reaction prepared from glucosamine," Jap J Nutr., vol. 44, pp. 307-315, 1986

[11] R. Re, N. Pellegrini, A. Proteggente, A. Pannala, M. Yang and C. Rice-Evans, "Antioxidant activity applying an improved ABTS radicalcationdecolorization assay," Free Rad Biol. Med., vol. 26, pp. 1231-1237, 1999.

[12] J. B. Harborne, "Phytochemical Methods: A guide to Modern Techniques of Plant Analysis," Chapman and Hall Ltd., London. 1973.

[13] M. A. T Phan,J. Paterson, M. Bucknall and J. Arcot, "Interactions between phytochemicals from fruits and vegetables: Effects on bioactivities and bioavailability," Critical Reviews in Food Science and Nutrition, vol. 58, pp. 1310-1329. 2016.

[14] S. Rashmi and H. G. Rajkumar, "Preliminary Phytochemical Analysis and in vitro Evaluation of Antifungal Activity of Five Invasive Plant Species against Macrophomina Phaseolina (Tassi) Goid," Int J. Plant Res., vol. 1, no. 1, pp. 11-15, 2011.

[15] K. H. Wagner and I. Elmadfa, "Biological relevance of terpenoids: Overview focusing on mono-di and tetraterpenes," Ann Nutr Metab., vol. 47, pp. 95-106, 2003.

[16] B. A. Akinpelu, O. A. Igbeneghu, A. I. Awotunde, E. O. Iwalewa and O. O. Oyadapo, "Antioxidant and antibacterial activities of saponin fractions of Erythropheleum suaveolens (Guill. and Perri.) stem bark extract." Scientific Research and Essays, vol. 9, no. 18, pp. 826-833, 2014

[17] D. Prakash, S. Suri, M. Upadhyay and B. N. Singh, "Total phenol, antioxidant and free radical scavenging activities of some medicinal plants," Int. J. Food Sci. Nutr., vol. 58, pp. 18-28, 2007.

[18] G. Piluzza and S. Bullitta, "Correlations between phenolic content and antioxidant properties in twentyfour plant species of traditional ethnoveterinary use in the Mediterranean area," Pharmaceutical Biology, vol. 49, no. 3 , pp. $240-247,2011$

Publish your research article in AIJR journals-

$\checkmark$ Online Submission and Tracking

$\checkmark$ Peer-Reviewed

$\checkmark$ Rapid decision

$\checkmark$ Immediate Publication after acceptance

$\checkmark$ Articles freely available online

$\checkmark$ Retain full copyright of your article.

Submit your article at journals.aijr.in

Publish your books with AIJR publisher-

$\checkmark \quad$ Publish with ISBN and DOI.

$\checkmark$ Publish Thesis/Dissertation as Monograph.

$\checkmark$ Publish Book Monograph.

$\checkmark$ Publish Edited Volume/ Book.

$\checkmark$ Publish Conference Proceedings

$\checkmark \quad$ Retain full copyright of your books.

Submit your manuscript at books.aijr.org 